\title{
Ethics and the Christian lives of clinicians
}

\author{
D.P. Sulmasy
}

Received: 4 November 2009 / Accepted: 21 January 2010 / Published online: 6 April 2010

(c) Springer-Verlag 2010

\begin{abstract}
While ethics is a very important aspect of medical care, it is important to note that ethical mistakes are most liable to be made when ethics becomes a pure abstraction. Reality comes before ethics. Ethics results from the encounter between free persons and the reality around them. Illness and injury are an important part of the human reality. Medical ethics is rooted in the encounter that one free person (the clinician) has with the reality of another person (the patient), whose freedom is limited by the stark realities of illness, injury, and death. Attending to the cry of the real is the surest road to truly good medical care. In fact, the Parable of the Good Samaritan can be interpreted not so much as a story about people's failure to obey moral rules as a story about the need to attend to the real and to respond appropriately. Good clinicians, like the Good Samaritan, begin by paying attention to reality.
\end{abstract}

Keywords Ethics $\cdot$ Freedom $\cdot$ Reality $\cdot$ Clinician $\cdot$ Patient Person

The names and circumstances have been altered slightly to protect patient confidentiality.

D.P. Sulmasy (西)

The MacLean Center for Clinical Medical Ethics

The University of Chicago, MC 6098

5841 S. Maryland Ave

Chicago, IL 60637 USA

email: dsulmasy@uchicago.edu
Ethics is really not as important as we make it out to be - even for physicians and nurses. Ethics is two or three steps removed from what is really important in health care; from what is really important in life. Ethics is not what it is cracked up to be.

\section{Ethics and freedom}

Ethics is really about human freedom and the world. Ethics "happens" because there is a world and we are free. It is unassailably true, except according to very obscure philosophies, that there is a world external to us. We also experience the fact that we have free will. The way we experience our freedom is through the fact that we act upon a world that is external to us and we make things happen. It is so simple and commonplace that the wonder of this experience usually escapes us. Yet, this is where ethics begins - at the interface between freedom and reality. The things that are most important then, most fundamental, are human freedom and reality. Freedom and reality are ontologically prior to ethics.

We need to be clearer, of course, particularly in the present era, about the true importance of freedom. Freedom is not the content of ethics. Freedom is not a good to be pursued for its own sake, such that the more things one is free to do the better one is as a person.

This is perhaps the most serious moral mistake of our time - the conflation of freedom and the good. Freedom is the context of morality, not its content. We only make moral judgments about what we are free to do or not do. As Aristotle puts it, ethics is about what to do, when what to do is up to us [1]. Freedom is not an intrinsic good; not something to be sought for its own sake.

Nonetheless, it would cheapen freedom to say that it is merely an instrumental good - something good only 
because it leads to what is good. Freedom is neither intrinsically nor merely instrumentally good. Freedom is the ontological ground of morality. It is, in this sense, a transcendental good. Freedom makes possible our judgments about right and wrong, good and evil. If we are not free, then we are not responsible, and there are no moral events. Freedom makes morality possible. Freedom is the possibility of pursuing good or evil. Freedom comes before ethics.

\section{Freedom and reality}

It is important to emphasize, however, that human freedom operates in the real world. That is why ethics is the most practical branch of philosophy - it is the process of deciding about what to do in the real world. The most amazing thing about us as human beings is that we dispose of our freedom in the face of reality, shaping that reality, changing that reality, for the better or for the worse. If our freedom had no real consequences, then ethics would not matter. One would be free to choose anything one desired and nothing actual would happen. That is why critical realism is vital to ethics. On the basis of what I have explained so far, one can readily see that if freedom is an illusion, then ethics is an illusion. Equally, but less obviously, one can also argue that if reality is an illusion, then ethics is an illusion. If nothing were real, then our choices would have no consequences and ethics would be pointless. The reality of the real is thus also ontologically prior to ethics.

The most important reality that we encounter in the world, especially with respect to how we dispose of our freedom, is the reality of other persons. In the reality of the real world, we encounter other persons who, like us, are free moral agents. It is in the human person that reality and freedom are linked. We also recognize in the community of persons some who are sick - who often have suffered the diminishment or even the eradication of their freedom. Speaking realistically (as I have insisted we must), we must always bear in mind that we first encounter the sick as persons. In fact, we only recognize them as sick because we first recognize them as persons and then take note of the restrictions sickness has wrought upon the freedom that ought properly to be theirs as persons [2].

Just as we must be careful not to conflate freedom with the good, we must be careful not to conflate freedom with reality. Freedom is not the sole reality, the one necessary and sufficient condition for being a person. Human beings are not persons to the extent that they are free. Human beings are the only archetype we have for persons. Human beings are persons because human beings are the only kinds of things we know that are typically capable of free moral agency. But this does not mean that when we encounter human beings whose freedom has been restricted, that they cease to be persons. Importantly for us as health care professionals, we first encounter patients always as persons [3].

We can only make the judgment that someone is sick by noting that he or she is a person whose freedom has been restricted by illness or injury. We have established our professions in order to help the sick because we have first judged them to be persons.

Nor is it up to us to decide by some arbitrary rule who is a person and who is not. Freedom encounters reality as something already given. We are not free to make up our own reality. Those who do so are mentally ill.

\section{Every ethos implies a mythos}

All of ethics, as I have argued, takes place at the interface between freedom and reality. One can conclude from this premise that all ethical systems, even secular systems of ethics, will always require faith. This again may seem puzzling. One might ask, can't atheists and agnostics be ethical? The answer is yes, but one must understand that an atheist or agnostic system of ethics still requires a system of faith. One way of putting it is thusly - every ethos implies a mythos [4].

By the word 'mythos' I do not mean the ordinary language word 'myth', but a comprehensive and fully developed narrative of the origins and nature of the world. Therefore, the phrase, "every ethos implies a mythos," means that every system of ethics, every view about how human freedom ought to be related to the reality of the world, requires (even if it is never made explicit) a comprehensive view about human freedom, the nature of the world, and, above all, about the persons who are part of the reality of the world and whose freedom is a form of dialogue with that real world. No system of ethics can get started without answering these questions.

The most fundamental question about ethics, then, is not just Aristotle's question about what we ought to do. The deeper and prior question is, which mythos should we accept as true before we start generating our ethos? What underlying story, what comprehensive account adequately corresponds to human freedom, to reality, to the person?

For example, we could accept the mythos that the world is just isolated bits of matter thrown together purposelessly; that human beings are just one more variation in this meaningless collection of atoms; that freedom is an illusion. This mythos will lead us to an ethos. If we believe this, so we will live.

Imagine, however, encountering a sick person and saying such things. Imagine looking into the eyes of a person dying of cancer and saying, "Look, don't be so upset. Everything is meaningless anyway. You grab as 
much pleasure as you can out of life and then it's over. So do you want another round of chemotherapy or not?"

Some might argue that this view about the meaninglessness of everything is the actual naked truth about the world. Such persons might argue further that this truth is just too much to bear; that the vast majority of us are actually cowards; and that we cover up the harshness of reality by inventing pleasant lies about the world and about ethics.

There is no logical proof that this is not the case. There is no logic, divorced from any premises about reality, that will disprove this thesis. But one can ask the fundamental question, why then, should we care for the sick? What would the point be? Why even ask the patient whether he or she accepts the risks and benefits of treatment with cisplatinum? Why should anyone have even bothered to invent cisplatinum? Why should one not try to persuade the patient that life is pointless; that cancer is pointless; that treatment is pointless; that death is pointless?

What would it matter if such talk upset the patient? Being upset or not; being a person who disturbs other persons or not, would also be pointless.

I think we find such thoughts disturbing not because we are afraid of the truth, but because the mythos of meaninglessness that I have described (which is not a straw man but is actually held by people who purport to be serious thinkers) is actually an unreasonable view. This mythos fails to account adequately for reality. It fails to acknowledge the wonder of the world. It fails to account for the obvious order and beauty. It fails to account for the mystery of the person. It fails to see what lies behind the fearful glance of the patient. It fails to account for the desire that leads human beings to become doctors or nurses or psychiatrists or medical researchers in the first place.

Fortunately, most health care professionals have had a different experience of reality. Most physicians and nurses have had a different encounter with the world. And those professionals who are Christians have a different notion of the world, one based on the fact they have encountered a person - a concrete, real, historical person - who provides a different mythos. This person, in fact, claims to be the one and only true mythos. The mythos Christians hold is that all was created through him; all was created for him; that he is before everything else that is; that in him everything holds together [5]. In him we live and move and have our being [6]. And what he says makes sense. What he says makes sense of reality. It makes sense of human freedom. It makes sense of ethics.

\section{The good Samaritan}

From Him we learn why we should care for the sick. He has told us a story that we know as the Parable of the
Good Samaritan [7]. Perhaps we would all benefit from a new twist on our understanding of this story, which can sometimes be so familiar that we fail to appreciate it fully.

One question to ask might be this: when the Priest and the Levite pass by the wounded man lying on the side of the road, what is their sin? Most of the time, we categorize their actions as ethical failures. Perhaps, however, we would gain a deeper insight into the parable if we were to see their problem not as an ethical lapse, but as a failure to see reality for what it is; a failure to respond with their freedom to the call of reality.

Suffering is real. Christianity is the religion of realism. Christianity helps us to see reality more clearly. Christianity does not hold, as some belief systems do, that suffering is only a mental attitude that can be overcome through meditative practices that help us to see that the cause of suffering is only our mental state, so that suffering can potentially disappear. Christianity teaches something quite different. Pray all you want and you will still suffer. Jesus learned this in the Garden of Gethsemane. Those of us who practice medicine, nursing, psychology, and the other healing arts know this all too well. Our job can be described, in many ways, as that of bearing witness to the suffering of the sick.

So, the sinfulness of the Priest and the Levite does not consist primarily in the fact that they decided not to help the half-dead man on the side of the road. One can readily surmise that they made no such conscious decision. Rather, they were probably living in their own private realities - pseudo-realities that prevented them from hearing the desperate cry of the real; from hearing Reality begging to be recognized for what it is; calling out to their freedom; seeking love. They did not want to dirty their hands with the reality of human suffering. They passed by because they failed to see what was real, and did not notice that their freedom was being beckoned.

By contrast, the Samaritan was a man of true faith. What matters in the parable is not, after all, his adherence to a moral code or a set of creedal propositions. These are important, but I want to re-emphasize that codes of ethics are of secondary importance. The Samaritan's faith is not born of his adherence to a moral code. He was not following a rule written somewhere that says when you see a man lying halfdead on the side of the road between Jerusalem and Jericho you should bind his wounds and take him to the nearest inn for recuperation. The Samaritan's faith is the faith of fidelity and trust. What matters in the parable is that the Samaritan is faithful to reality and to its call. He is faithful to persons. He sees that it is a person who is suffering and he responds in freedom because he sees clearly. His relationship to the man is marked by fidelity.

The Samaritan is also a man of trust. He trusts in the innkeeper to take care of the injured person. In turn, he 
trusts that the innkeeper will trust him to pay the difference upon his return. The faith born of trust and fidelity is the faith of a man who sees reality as significant and life-affirming, as corresponding to him and to the innkeeper and to the man on the side of the road, who are both persons. The ethics, then, is derivative. It consists in freedom's response to reality's call.

\section{Clinical ethics and reality: a story}

I work as a clinical ethicist in a university hospital. If I now attempt to justify why it is that I do what I do, I have, of course, made my job harder. I have been arguing that ethics is not so important. By doing so, I have perhaps also jeopardized my income since I am, in fact, paid to do ethics consults. Perhaps I should be sure that those who endowed my chair never learn about this essay, or they will retract their gift.

Allow me to start by saying that doing ethics consults is never easy. The day it becomes easy is the day I should hang up my stethoscope and go home. In doing ethics consults, I am dealing with real persons in incredibly trying circumstances, often treading on the narrow ridge between life and death. Sometimes people are angry. Sometimes they are in denial. Sometimes the spires of the hospital towers cry out to the heavens in the face of unspeakable and insoluble injustice. There are also moments in which patients and families face grueling, miserable trials with all the faith, hope, and love of which the Gospels speak, and I am profoundly moved. Regardless of the outcome of the consult, whether we reach a reasonable resolution or not, whether the parties involved were saints or sinners, I always seem to come back to my office with a feeling of emotional exhaustion, as if the marrow had been sucked out of my bones.

Let me tell you briefly about one of these consults. Antonio Alvarez was dying of end-stage HIV infection. He had been only intermittently compliant with his anti-retroviral regimen, and had developed significant resistance. He had lymphoma, hepatitis $\mathrm{C}$, renal failure, and MRSA sepsis. He was comatose and on a ventilator in the intensive care unit. His mother, Rosa, who had been summoned from her home in Puerto Rico because of the gravity of his situation, had only learned that he had AIDS two days before. The intensivists had suggested an order that he not be resuscitated, that he be removed from the ventilator, and that he be given comfort measures until he died. The patient's sister, Maria, who also lived in New York and had been caring for him (as much as he would permit) during the eight-year course of his HIV infection, insisted that the physicians continue any and all life-prolonging measures. She stated that she thought he would want these - that he did not want to die and that he was "a fighter." Rosa was inclined to discontinue life support but worried that she would be violating her son's wishes and also worried that she would be violating the teachings of the Church.

We convened an ethics consult. It wasn't pretty. Rosa was crying. Maria was yelling. The intensivists could barely restrain their looks of frustration. We had already been there an hour, their dispassionate descriptions of the medical facts did not seem to matter, and it seemed as if no resolution were in sight.

I don't generally tell my patients that I am a Franciscan friar - certainly not when I first meet them. Most of the time, it is not immediately relevant that they know this fact overtly. It is far more important that I strive to treat them in a manner worthy of my vocation than that they should know this fact about me explicitly. But in this case it seemed that it might be helpful. I handed Mrs. Alvarez a fresh box of tissues. I asked her if she knew Fray Roberto Gonzalez, the Archbishop of San Juan. I told her that I was also a friar and had lived with Arzobispo Gonzalez in the Bronx in the mid-1980s. I told her that I was sorry she had to find herself thrust into such trying circumstances, and that it must have been very difficult to learn of her son's diagnosis so abruptly and to see him so sick. I then explained to her how the Church did not require that all life-extending treatments be used, but had for centuries taught that treatments that were considered "extraordinary," that is, treatments that seemed inordinately burdensome compared with the benefits, could be discontinued. I explained that what the doctors were really trying to say was that God was calling her son home, and that no matter what they did, they were going to be powerless in the face of God's call. All that we needed to decide was whether, under such circumstances, her son would consider this attempt to stop the inevitable, at the cost of great suffering, something he would be determined to go through. But that the merciful thing to do right now would probably be to let him go.

Tearfully, she said she did not think he would want to fight only for the sake of fighting. It would be OK to stop the ventilator.

Maria was furious. "He is a fighter, Mama," she said. "You don't know what I've been through with him. You've been in Puerto Rico. I've been the one here with him all the time while he's been sick. You didn't even know he had AIDS."

Her words cut Rosa to the heart, just as they were intended to do. Rosa was visibly shaken, trembling, but she stood her ground against this verbal onslaught from her daughter. "Enough is enough," she said. "Let him go."

"This is your decision, remember. Your decision," said Maria. Then she got up and stormed out of the room, never to return to the hospital again. 
Later that evening, the ventilator was discontinued, after administering a small dose of morphine for comfort. As often happens, however, Mr. Alvarez did not die immediately. Breathing slowly, but nonetheless still breathing, he lingered. The nurses were attentive to his symptoms, watching and treating any signs of pain or agitation. They relaxed the visiting hours, and even let Rosa sleep on a cot in the room with her son overnight.

The next morning I made a follow-up visit to see what had happened after our ethics consult. The ICU team was rounding at the other end of the unit. I entered the room and saw Mrs. Alvarez sitting at the side of the bed, caressing her son's face, brushing back his hair.

"How are you doing with all this?" I asked.

"Oh doctor," she said. "Dios mío. Dios mío."

"He looks peaceful," I said.

"Oh doctor, how long? How much longer before God take him?"

"I can't really say," I replied. "Not too much longer, I don't think. Not too much longer."

I pulled up a chair and sat next to her as she sat next to her son. We said nothing. She had obviously had little sleep and was exhausted - in body and in soul. She started to weep again, softly.

"Está bien," I said. "Está bien," and I reached out and touched her on the wrist.

Then I did something I do not often do, but on this occasion it seemed exactly the right thing to do at exactly the right moment. The room was filled with a very warm but faint light. The shades were all drawn and the lights turned off so that the room was dark, but the sun had obviously risen and was shining around the edges of the window where the shades could not contain its brilliance. This gave the ICU room the soft radiance of a parlor illuminated by the glow of a fireplace. With my hand still touching her wrist I began, "Padre Nuestro, que estás en los cielos..."

Fortunately for me she picked up my cue and began to pray along. I knew how to start the Our Father in Spanish, but did not know how to end. But by praying with her, I could pray it through to the end.

"Dios te bendiga," I said. And I left.

Antonio Alvarez died later that morning.

Of course the ethics mattered in this case. I do not want to deny that. But the reason I have told this story is to illustrate how the ethics were really secondary. What mattered most was the reality of this situation - the suffering, the anger, the confusion, the hurtfulness, the love of a mother for her son. What mattered was Antonio. What mattered was Rosa. What mattered was Maria. What mattered was how far I, as a person, was able to be open to the power and the fury and the beauty of that reality. What mattered was how I, a free person, responded to that reality.

\section{Clinical ethics and Christianity: a parable}

Why should we care for the sick? Why should we do clinical ethics consults?

Why should anyone do research or speak or write about medical ethics? Why should anyone become a nurse or a physician or a psychologist or a biomedical researcher?

Let me answer with a parable.

A patient with dementia was admitted to a hospital with a broken hip. She began to wail aloud, asking, "Would somebody please help me?"

The Chief of Geriatrics came down the hall, but he rushed by because he was on his way to attend an important meeting about billing and electronic medical records in the Department of Medicine.

A senior resident then came down the hall, but since he was from another team and it was not his patient, continued down the hall to take the stairs to another ward in order to do the H\&P on his latest admission.

Next down the hall came a third year medical student on her first rotation, who had barely passed her basic science courses, and then only with extraordinary effort, and had been thinking of quitting medical school. She heard the cry and went into the room. She quickly realized that the patient was in pain and might also have been delirious. She calmed the patient down with a soothing voice and a gentle touch. She then went to the nursing station, found that the patient had an order for prn morphine, reported the patient's condition, and asked the nurse to administer an immediate dose, promising to find the patient's intern and ask him to assess whether there might not be a superimposed delirium afflicting the patient as well.

Which of these three would you say was physician to this patient?

Go thou and do likewise.

\section{Conflict of interest: none}

\section{References}

1. Aristotle (1999) Nichomachean ethics. 2nd edn, 1113a.10-1113b.21, T Irwin, trans. Indianapolis, Hackett, pp. 36-38

2. Pellegrino ED, Thomasma DC (1981) A philosophical basis of medical practice. New York: Oxford University Press pp. 208-209

3. Ramsey P (1970) The patient as person. New Haven, Yale University Press

4. Sulmasy DP (1999) Every ethos implies a mythos: bioethics and faith. In Davis DS, Zoloth L (eds): Notes from a narrow ridge: religion and bioethics. Frederick, University Publishing Group pp. 227-246

5. Col 1:17

6. Acts $17: 28$

7. Lk 10:29-37 